\title{
STRATEGI PENINGKATAN KOMPETENSI LULUSAN PERGURUAN TINGGI MELALUI STUDI PELACAKAN ALUMNI (TRACER STUDY)
}

\author{
Rofi Rofaida ${ }^{1}$, Budhi Pamungkas Gautama ${ }^{2}$ \\ ${ }^{1,2}$ Program Studi Manajemen, Fakultas Pendidikan Ekonomi dan Bisnis, \\ Universitas Pendidikan Indonesia, Bandung, Indonesia. \\ rofi.rofaida@upi.edu ${ }^{1}$, budhipamungkas@upi.edu ${ }^{2}$
}

\begin{abstract}
The purpose of this study is to find a picture of the competencies of graduates, find a picture of the competencies of industry demands, find a picture of the competency gap held by graduates with the demands of the world of work / industry, and determine the quality assurance strategy of tertiary institutions based on the results of tracer tracking studies (tracer study). The research conducted is qualitative research. The unit of analysis is a graduate of the Management Study Program Faculty of Economics and Business, Universitas Pendidikan Indonesia. The sampling method used was purposive sampling with a sample of 100 graduates. The research method used is descriptive survey method. The results showed that competencies that still needed to be improved were English, computers, teamwork, written communication, oral communication, community empowerment, and leadership. Improving the quality of education in the Management study program can be done through improving the quality of education, research, and community service, as well as cooperation with industry.
\end{abstract}

Keywords: competence of graduates; higher education quality assurance; tracer study

\begin{abstract}
Abstrak
Tujuan penelitian ini adalah untuk mengetahui gambaran mengenai kompetensi yang dimiliki lulusan, mengetahui gambaran mengenai kompetensi tuntutan industri, mengetahui gambaran mengenai kesenjangan kompetensi yang dimiliki lulusan dengan tuntutan dunia kerja/industri, dan menentukan strategi penjaminan mutu perguruan tinggi didasarkan pada hasil studi pelacakan lulusan (tracer study). Penelitian yang dilakukan adalah penelitian kualitatif. Unit analisis adalah lulusan Program Studi Manajemen Fakultas Pendidikan Ekonomi dan Bisnis Universitas Pendidikan Indonesia. Metode pengambilan sampel yang digunakan adalah purposive sampling dengan sampel 100 orang lulusan. Metode penelitian yang digunakan adalah metode survei deskriptif. Hasil penelitian menunjukkan bahwa kompetensi yang masih harus ditingkatkan adalah bahasa Inggris, komputer, kerjasama tim, komunikasi tertulis, komunikasi lisan, pemberdayaan masyarakat, dan kepemimpinan. Peningkatan kualitas pendidikan di program studi Manajemen dapat dilakukan melalui peningkatan kualitas pada pendidikan, penelitian, dan pengabdian kepada masyarakat, serta kerjasama dengan industri.
\end{abstract}

Kata Kunci: kompetensi lulusan; penjaminan mutu perguruan tinggi; studi pelacakan lulusan

Corresponding author: Email : rofi.rofaida@upi.edu

History of article : Received: Desember 2018, Revised : Februari 2019, Published: April 2019 


\section{PENDAHULUAN}

Visi Universitas Pendidikan Indonesia untuk menjadi Universitas Pelopor dan Unggul (a leading and outstanding university) menuntut universitas untuk senantiasa menanggapi perkembangan ilmu pengetahuan, teknologi, seni, budaya, dan tuntutan masyarakat dengan peningkatan sistem penyelenggaraan pendidikan. Perubahan perguruan tinggi menjadi universitas dan statusnya menjadi UPI BHMN memberikan keleluasaan untuk mengelola perguruan tinggi secara otonomi. Disisi lain hal ini merupakan tantangan bagi UPI untuk menghasilkan lulusan yang memiliki kualitas lebih baik dalam suatu proses penyelenggaraan pendidikan dan manajemen pendidikan yang lebih berkualitas, transparan, dan efisien. Ini menjadi mutlak untuk dilakukan karena tantangan lain yang dihadapi oleh seluruh perguruan tinggi di Indonesia, termasuk UPI adalah dampak yang ditimbulkan dari globalisasi sektor pendidikan dan ketenaga kerjaan. Globalisasi memungkinkan kompetisi tidak dibatasi oleh batas geografis dan sosiokultural antar negara. Kompetisi yang terjadi adalah (1). kompetisi antar institusi pendidikan, dan (2). kompetisi lulusan di pasar tenaga kerja

Kompetisi antar institusi pendidikan memberikan arti bahwa UPI berkompetisi tidak hanya dengan perguruan tinggi negeri dan swasta nasional tetapi juga dengan perguruan tinggi asing yang mulai masuk ke Indonesia. Keberadaan Monash University yang berafiliasi dengan perguruan tinggi Indonesia, hanya salah satu contoh meningkatnya kompetitisi di bidang pendidikan perguruan tinggi. Di pasar tenaga kerja, lulusan UPI menghadapi kompetisi yang cukup 'keras' dengan lulusan dari perguruan tinggi lain baik perguruan tinggi dalam negeri maupun luar negeri.

Khusus untuk program studi non kependidikan yang ada di Fakultas Ekonomi dan Bisnis (FPEB) Universitas Pendidikan Indonesia (UPI), yaitu program studi Manajemen merupakan program studi yang memiliki potensi keberlangsungan (sustainibility) yang cukup tinggi. Sejak dibuka pada tahun 2002 sampai tahun 2017, animo calon mahasiswa untuk mendaftar ke program studi ini cukup tinggi, selalu termasuk kedalam tiga besar di UPI dalam jumlah pendaftar (UPI, 2017). Gambaran ini di satu sisi menjadi sesuatu yang menggembirakan namun di sisi lain menjadi tantangan bagi Program Studi Manajemen didasarkan pada pemikiran bahwa di kota Bandung tercatat lebih dari 50 universitas atau sekolah tinggi baik negeri maupun swasta menyelenggarakan jurusan / program studi sejenis. Tanggung jawab moralnya adalah melaksanakan program pendidikan yang mampu menghasilkan lulusan yang memiliki daya saing tinggi di pasar tenaga kerja.

Permasalahan yang dihadapi oleh program studi non kependidikan di UPI, khususnya program studi Manajemen adalah sebagai berikut :

1. Tingkat persaingan di pasar tenaga kerja antara lulusan manajemen UPI dengan lulusan universitas lain sangat tinggi, karena banyak universitas atau sekolah tinggi yang menyelenggarakan jurusan/program studi yang sama.

2. Promosi yang diselenggarakan oleh program studi dan UPI kepada masyarakat maupun industri sangat minim, sehingga kalangan industri (perusahaan swasta, BUMN, dan instansi pemerintah) belum mengetahui bahwa lulusan UPI dapat bekerja di sektor non kependidikan

3. Tingkat kepercayaan industri terhadap lulusan harus ditingkatkan.

Pemecahan masalah-masalah di atas pada dasarnya dapat dilakukan melalui peningkatan kualitas penyelenggaraan pendidikan seperti kurikulum yang sesuai dengan tuntutan industri/pasar tenaga kerja, sarana dan prasarana pendidikan yang memadai dan aspek lainnya. Salah satu sumber informasi untuk mengetahui sejauhmana kualitas penyelenggaraan pendidikan yang dilakukan adalah melalui kualitas lulusan yang dihasilkan, daya saing lulusan UPI dengan universitas lain, dan daya serap industri terhadap lulusan. Salah satu instrument yang dapat digunakan adalah melalui studi pelacakan alumni (tracer study).

Tujuan penelitian ini adalah untuk mengetahui gambaran mengenai kompetensi yang dimiliki lulusan,meng metahui gambaran mengenai kompetensi tuntutan dunia 
kerja/industri,mengetahui gambaran mengenai kesenjangan kompetensi yang dimiliki lulusan dengan tuntutan dunia kerja/industri, dan menentukan strategi penyelenggaraan pendidikan didasarkan pada hasil studi pelacakan lulusan (tracer study).

Kontribusi yang diberikan dari hasil penelitian ini adalah menjadi base line study dalam menentukan kebijakan/strategi peningaktan kualitas penyelenggaraan pendidikan di Program Studi Manajemen UPI, menjadi informasi bagi stake holder (masyarakat dan dunia kerja) dalam pengambilan keputusan penggunaan lulusan program studi Manajemen, dan medorong dilakukan penelitian lanjutan untuk program studi lain di lingkungan UPI

\section{KAJIAN PUSTAKA}

\section{Kualitas Penyelenggaraan Pendidikan pada Perguruan Tinggi}

American Society for Quality dalam Russel dan Taylor (2013) mendefinisikan kualitas sebagai : The characteristics of $a$ product or service that bear on its ability to satisfy stated or implied needs. Kualitas adalah totalitas karakteristik produk baik barang maupun jasa yang menunjukkan kemampuannya untuk memuaskan kebutuhan konsumen baik yang dinyatakan secara eksplisit maupun yang bersifat implisit. Kualitas produk yang dihasilkan (barang atau jasa) merupakan faktor yang strategis dalam menentukan kinerja perusahaan, terutama kinerja finansial (O'Neill, Peter, et al, 2016). Pentingnya kualitas produk membutuhkan pengelolaan/manajemen kualitas yang akan menentukan bagaiman aktifitas bisnis di dalam perusahaan untuk menghasilkan produk yang memiliki kualitas tinggi (Talib, Faisal, et al, 2013). Kualitas menjadi keunggulan bersaing perusahaan (competitive advantage) melalui pemenuhan kepuasan konsumen. Pada pendekatan ini riset pasar diperlukan untuk mengetahui kebutuhan dan keinginan konsumen. Rangkaian proses ini menghasilkan kepuasan konsumen yang berujung pada keunggulan bersaing perusahaan. Konsumen yang puas dan pada akhirnya akan menjadi loyal akan menghasilkan organisasi yang efektif dan memiliki keunggulan bersaing. Pada titik ini organisasi dapat menghantarkan produk (baik barang dan jasa) yang sesuai dengan ekspektasi/harapan konsumen. Perbaikanperbaikan selalu dilakukan melalui employee fulfillment (pemberdayaan karyawan yang berkualitas), quality principles (proses produksi yang berkualitas), dan organizational practices (manajemen organisai yang efektif).

Perguruan tinggi adalah perusahaan jasa. Terdapat 7 dimensi pengukuran dalam kualitas jasa yaitu: Time and timeliness (ketepatan waktu penghantaran jasa), Completeness (kelengkapan layanan jasa yang diberikan), Courtessy (sikap dan tingkat keramahan SDM dalam memberikan layanan), Consistency (konsistensi kualitas layanan yang diberikan untuk setiap konsumen pada waktu yang berbeda, Accessibility and convinience (kemudahan dalam memperoleh layanan jasa), Accuracy (kualitas layanan jasa yang diberikan), Responsiveness (Tingkat responsifitas perusahaan dalam memberikan pelayanan, termasuk dalam menangani permasalahan kualitas yang di bawah standar). (Russel \&Taylor, 2013; Supranto, 2006). Riset yang dilakukan Abdullah, F, et al (2011) menggunakan instrument SERVQUAL untuk mengukur kualitas jasa pada sektor perbankan. Mengacu kepada hasil penelitian Tan \& Kek (2004) menyatakan bahwa, Pentingnya menggunakan Servqual sebagai instrument untuk mengukur kualtias jasa pendidikan yang diberikan oleh perguruan tinggi. Survey dilakukan kepada lulusan untuk menilai efektifitas dan kualitas jasa pendidikan, memberikan feedback, dan memberikan motivasi kepada perguruan tinggi

Penerapan prinsip kualitas di atas adalah bahwa sebagai perusahaan jasa, perguruan tinggi harus dapat memberikan layanan pendidikan sesuai dengan harapan pengguna layanan pendidikan. Perbaikan secara terus menerus harus dilakukan karena harapan pengguna juga akan berkembang secara dinamis. Penilaian terhadap kualitas layanan pendidikan dapat dilakukan melalui pengukuran terhadap tujuh dimensi di atas.

Untuk memberikan informasi mengenai kualitas layanan pendidikan kepada masyarakat, perguruan tinggi memerlukan penilaian dan pengakuan dari lembaga sertifikasi misalnya dalam bentuk Akreditasi 
Perguruan Tinggi oleh BAN PT dan serifikasi ISO oleh badan sertifikasi independen.

Kualitas pada perguruan tinggi secara eksplisit didefinisikan sebagai Standards of all criteria which fulfill the expectations of the university and stakeholders. Kualitas pada perguruan tinggi adalah keseluruhan standar yang menjadi ekspektasi/harapan universitas dan stakeholders. Kualitas memberikan arti : (1) memenuhi standard kinerja yang ditetapkan, (2).memenuhi tujuan yang telah ditentukan (fitness for purpose), (3). tanpa kesalahan (zero defect), (4).Excellency, kesempurnaan, dan (5). memenuhi kepuasan stakeholders

Penjaminan kualitas di perguruan tinggi, dikenal dengan istilah Sistem Penjaminan Mutu. Sistem Penjaminan Mutu merupakan sebuah perwujudan peningkatan proses perguruan tinggi yang berkualitas, namun secara umum definisinya adalah:

1) Sistem Penjaminan Mutu adalah suatu sistem manajemen untuk mengarahkan dan mengendalikan suatu organisasi/institusi dalam penetapan kebijakan, sasaran, rencana dan proses/prosedur mutu serta pencapaiannya secara berkelanjutan (continous improvement).

2) Sistem Penjaminan Mutu adalah suatu sistem manajemen yang menjamin kesesuaian antara proses dengan output yang dihasilkan yang akan memberikan kepuasan stakeholders.

3) Sistem Penjaminan Mutu merupakan sistem manajemen yang terdiri dari struktur organisasi, tanggung jawab, proses-proses, prosedur dan sumber daya yang digunakan untuk mencapai standar yang ditentukan berdasarkan persyaratan dan kebutuhan stakeholders dan organisasi

4) Sistem Penjaminan Mutu adalah Sistem manajemen yang mengikutsertakan seluruh karyawan dari tingkatan organisasi, dengan penerapan konsep pengendalian kualitas dan metode statistik untuk mencapai kepuasan pelanggan dan yang mengerjakannya

Sistem penjaminan mutu adalah aktualisasi dari Undang Undang Nomor 44 tahun 2015 tentang Standar Nasional
Perguruan tinggi (SNPT) dan Peraturan Presiden No 8 tahun 2012 tentang Kerangka Kualifikasi Nasional Indonesia (KKNI), bahwa proses pembelajaran perguruan tinggi menggunakan satu atau lebih pendekatan, model, strategi, metode pembelajaran untuk memfasilitasi pemenuhan capaian pembelajaran lulusan yang berorientasi pada kemampuan Abad 21 dan KKNI level 6.

Hedwid \& Polla (2006) menjelaskan bahwa penyelenggaraan pendidikan di perguruan tinggi yang merupakan tridharma PT, ditentukan oleh visi, misi, sasaran mutu, dan kompetensi yang ditetapkan. Infrastruktur, sumberdaya manusia, dan nilai budaya menjadi faktor pendukung. Pada akhirnya masukan dari alumni, industri, dan masyarakat akan menentukan perbaikan-perbaikan untuk meningkatkan kualitas secara berkesinambungan (continuously quality improvement).

\section{Kompetensi Lulusan Perguruan Tinggi}

Kompetensi mengarah kepada karakteristik dan perilaku yang dibutuhkan individu untuk dapat melakukan pekerjaan dan usahanya secara memuaskan. Karakteristik mengacu kepada pengetahuan serta keterampilan yang individu miliki serta individu butuhkan untuk membuat mereka mampu dalam melakukan tugas serta tanggungjawab dengan efektif sehingga dapat meningkatkan kualitas usaha yang telah dilakukan. (Spencer \& Spencer, 2003; Robbins, 2013). Suatu kompetensi haruslah merupakan kecakapan serta kemampuan yang sifatnya lebih (dibandingkan pesaing) atau di atas rata-rata yang dimiliki seseorang dalam menghasilkan kinerja yang memuaskan.Kompetensi berkaitan dengan pengetahuan, keahlian, kemampuan, dan karakteristik personal yang secara langsung mempengaruhi kinerja secara individu, kinerja kepada stakeholders dan kepada kinerja bisnis (Ulrich,2017). The IRS Handbook on Competencies: Law and Practise (2001), membagi kompetensi menjadi dua, yaitu : technical competencies, sering disebut sebagai hard competencies atau job related competencies, yaitu pengetahuan (knowledge) dan keterampilan (skill). Kedua adalah behavioral competencies, sering disebut soft competencies, adalah kompetensi yang 
ditentukan oleh perilaku atau sikap mental. Young \& Chapman (2010) meneliti mengenai Kompetensi generik yang harus dimiliki lulusan.

\section{Studi Pelacakan Alumni (Tracer Study)}

Studi pelacakan jejak alumni atau

Tracer Study merupakan survey lulusan yang dilakukan perguruan tinggi untuk memperoleh gambaran beberapa faktor seperti :

1. Memperoleh gambaran mengenai kompetensi yang dimiliki lulusan baik comparative competency advantage maupun competitive competency advantage

2. Memperoleh gambaran mengenai kompetensi tuntutan dunia kerja/industri

3. Memperoleh gambaran mengenai kesenjangan kompetensi yang dimiliki lulusan dengan tuntutan dunia kerja/industri

4. Menjadi masukan dalam pengembangan strategi penyelenggaraan pendidikan (pengembangan kurikulum, strategi pembelajran, dan aspek lain) pada level program studi, fakultas, dan universitas

5. Menjadi informasi bagi stakeholder (industri dan masyarakat) mengenai kompetensi lulusan

6. Menjadi salah satu sarana untuk pencitraan program studi dan universitas

7. Menjadi salah satu indikator penjaminan mutu perguruan tinggi/akreditasi dan akuntabilitas institusi pendidikan

Peran tracer study semakin penting karena dapat memberikan informasi penting untuk pengembangan perguruan tinggi, berperan sebagai alat evaluasi relevansi antara pendidikan tinggi dan dunia kerja dan dapat menjadi masukan yang berguna bagi lulusan untuk meningkatkan kompetensi. Bagi stakeholders hasil tracer study dapat menjadi dasar pertimbangan dalam pemilihan perguruan tinggi yang diinginkan

\section{METODE PENELITIAN}

Penelitian yang dilakukan adalah penelitian kualitatif. Penelitian ini lebih menekankan pada mengetahui makna yang tersembunyi, untuk memahami interaksi sosial, untuk mengembangkan teori, untuk memastikan kebenaran data, dan meneliti sejarah perkembangan. Objek penelitian adalah variabel yang akan diteliti yaitu gambaran mengenai kompetensi yang dimiliki lulusan, kompetensi tuntutan dunia kerja/industri, mengetahui gambaran mengenai kesenjangan kompetensi yang dimiliki lulusan dengan tuntutan dunia kerja/industri, dan menentukan strategi penyelenggaraan pendidikan didasarkan pada hasil studi pelacakan lulusan (tracer study)

Pengukuran variabel penelitian dilakukan melalui pengukuran indikatorindikatornya. Jenis data yang dikumpulkan terdiri dari data pribadi (jenis kelamin, usia, dan riwayat pekerjaan), technical competency, dan behavioral competency. Indikator technical competency dan behavioral competency. Indikator technical competencies terdiri dari penguasaan pengetahuan umum, penguasaan pengetahuan teoritis dan praktis sesuai bidang studi, penguasaan bahasa Inggris, penguasaan computer, penguasaan metode penelitian, dan teknologi informasi. Behavioral competency meliputi integritas, kemampuan bekerjasama dalam tim, kemampuan komunikasi secara tertulis, kemampuan komunikasi secara lisan, pemberdayaan masyarakat, kepemimpinan, dan manajemen organisasi.

Penelitian yang dilakukan adalah penelitian kualitatif.. Unit analisis adalah lulusan Program Studi Manajemen Fakultas Pendidikan Ekonomi dan Bisnis Universitas Pendidikan Indonesia. Metode penelitian yang digunakan adalah metode survei deskriptif Metode survei menggunakan kuesioner sebagai alat pengumpulan data yang utama. Metode pengumpulan data adalah observasi lapangan, kuesioner, dan waaancara. Hasil penelitian kemudian dianalisis secara deskriptif. Ukuran sampel adalah sebanyak 100 oang lulusan.

\section{HASIL DAN PEMBAHASAN}

Dari hasil tracer study dapat diidentifikasikan bahwa lulusan terdiri dari pria sebanyak $45 \%$ dan wanita sebanyak $55 \%$, rentang usia 26 sampai 32 tahun, dengan rata rata telah bekerja di dua perusahaan yang 
berbeda. Lulusan bekerja di lembaga pemerintahan (7,368\%), BUMN/BUMD $(27,368 \%)$, sektor swasta $(53,684 \%)$, dan sisanya $(11,579 \%) \quad$ sebagai seorang wirausaha/entrepreneur. Gambaran ini menunjukkan bahwa lulusan program studi Manajemen diperlukan dan bisa memasuki berbagai sektor bisnis termasuk berwirausaha. Persaingan untuk memperoleh pekerjaan tentu akan semaikn tinggi sehingga strategi pendidikan untuk tahun yang akan datang adalah menciptakan lulusan sebagai 'job creator' bukan sebagai 'job seeker'. Sehingga lulusan akan berperan dalam penciptaan lapangan kerja bukan hanya untuk dirinya sendiri tetapi juga untuk masyarakat luas. Kurikulum harus diarahkan dan diperkuat untuk mengembangkan ide ide kreatif mahasiswa dan memperkuat kompetensi kewirausahaan.

Lulusan yang bekerja sebagin besar berada pada posisi tenaga teknis/operasional sebanyak $60 \%$ dan menempati posisi sebagai staf (40\%). Lulusan berpendapat bahwa saat ini lulusan program studi Manajemen sangat mampu bersaing di pasar tenaga kerja $(55 \%)$ dan mampu untuk bersaing (45\%). Hampir seluruh lulusan $(94,50 \%)$ bekerja sesuai dengan keahliannya dengan rata-rata masa tunggu dari mulai lulus sampai memperoleh pekerjaan adalah tiga bulan. Gambaran ini menjadia masukan bagi program studi Manajemen untuk lebih meningkatkan technical competency untuk mempersiapkan lulusan jika menempati posisi teknis dan manajerial serta behavioral competency untuk mempersiapkan lulusan menempati posisi staf dan manajerial.

Hasil penelitian berkaitan dengan kompetensi teknis dan kompetensi perilaku dapat diringkas seperti dapat dilihat pada Tabel 1.

Tabel 1. Technical Competency dan Behavioral Competency Lulusan Program Studi Manajemen Universitas Pendidikan Indonesia

\begin{tabular}{|l|c|c|c|}
\hline \multicolumn{1}{|c|}{$\begin{array}{c}\text { Indikator } \\
\text { Kompetensi }\end{array}$} & $\begin{array}{c}\text { Skor } \\
\text { Kemam } \\
\text { puan }\end{array}$ & $\begin{array}{c}\text { Skor } \\
\text { Kebutu } \\
\text { han }\end{array}$ & Gap \\
\hline $\begin{array}{l}\text { Pengetahuan } \\
\text { umum }\end{array}$ & 3,2 & 3,1 & 0,1 \\
\hline $\begin{array}{l}\text { Pengetahuan } \\
\text { teoriti sesuai } \\
\text { bidang studi }\end{array}$ & 2,7 & 2,7 & 0 \\
\hline
\end{tabular}

\begin{tabular}{|l|c|c|c|}
\hline \multicolumn{1}{|c|}{$\begin{array}{c}\text { Indikator } \\
\text { Kompetensi }\end{array}$} & $\begin{array}{c}\text { Skor } \\
\text { Kemam } \\
\text { puan }\end{array}$ & $\begin{array}{c}\text { Skor } \\
\text { Kebutu } \\
\text { han }\end{array}$ & Gap \\
\hline $\begin{array}{l}\text { Pengetahuan } \\
\text { praktis sesuai } \\
\text { bidang studi }\end{array}$ & 2,6 & 2,6 & 0 \\
\hline Bahasa Inggris* & 3 & 3,7 & $-0,7$ \\
\hline Komputer* & 3,1 & 3,9 & $-0,8$ \\
\hline $\begin{array}{l}\text { Metode } \\
\text { penelitian }\end{array}$ & 2,8 & 2,6 & 0,2 \\
\hline $\begin{array}{l}\text { Teknologi } \\
\text { informasi }\end{array}$ & 3,5 & 3,4 & 0,1 \\
\hline Integritas & 3,4 & 3,3 & 0,1 \\
\hline Kerjasama tim* & 3,5 & 4 & $-0,5$ \\
\hline $\begin{array}{l}\text { Komunikasi } \\
\text { tertulis* }\end{array}$ & 3,3 & 3,6 & $-0,3$ \\
\hline $\begin{array}{l}\text { Komunikasi } \\
\text { lisan* }\end{array}$ & 3,4 & 3,7 & $-0,3$ \\
\hline $\begin{array}{l}\text { Pemberdayaan } \\
\text { masyarakat* }\end{array}$ & 2,8 & 3,2 & $-0,4$ \\
\hline Kepemimpinan * & 3,2 & 3,6 & $-0,4$ \\
\hline $\begin{array}{l}\text { Manajemen } \\
\text { organisasi }\end{array}$ & 3,4 & 3,4 & 0 \\
\hline
\end{tabular}

Skor kemampuan menunjukkan kemampuan yang saat ini dimiliki lulusan sedangkan skor kebutuhan menunjukkan skor yang seharusnya dimiliki oleh lulusan. Gap adalah ketidaksesuaian antara skor kemampuan dengan skor kebutuhan. Indikator kompetensi perlu mendapatkan perhatian atau perlu ditingkatkan jika skor kemampuan kurang dari skor kebutuhan (deviasi negatif). Dari Tabel 1 dapat diidentifikasikan bahwa indikator yang masih perlu ditingkatkan adalah Bahasa Inggris, komputer, kerjasama tim, komunikasi tertulis, komunikasi lisan, pemberdayaan masyarakat, dan kepemimpinan.

Beberapa strategi yang perlu dilakukan oleh program studi Manajemen untuk meningkatkan kualitas pelayanan pendidikan untuk meningkatkan kompetensi lulusan adalah sebagai berikut :

1. Meningkatkan kualitas dan akuntabilitas penyelenggaraan tridharma perguruan tinggi melalui pemenuhan standar-standar penjaminan mutu perguruan tinggi.

2. Pengembangan kurikulum secara terus menerus sesuai dengan perkembangan ilmu dan teknologi serta tuntutan industri/dunia usaha

3. Melakukanbenchmarking penyelenggaraan kegiatan perguruan tinggi ke universitas berkualitas di dalam dan luar negeri 
4. Mengoptimalkan peran dosen PA dalam memberikan layanan/bantuan tutorial akademik, bimbingan karir, konseling pribadi, dan sosial

5. Mengembangkan sistem baku untuk meningkatkan keterkaitan program studi dengan mahasiswa melalui Ikatan Mahasiswa Manajemen (IMAGE) dalam kegiatan penelitian dan pengabdian pada masyarakat

6. Meningkatkan kualitas program pengembangan profesionalisme dosen melalui keikutsertaan secara aktif dalam : seminar, pelatihan, worskshop, dan studi lanjut

7. Mendorong dosen untuk menyusun karya ilmiah dalam bentuk buku dan tulisan dalam jurnal baik jurnal nasional maupun jurnal internasional yang terakreditasi

8. Membangun kelompok-kelompok kajian/research berdasarkan keahlian/kompetensi

9. Menambah kuantitas dan kualitas tenaga pendukung melalui sistem seleksi yang akuntabel dan transparan, serta pelatihan berbasis kebutuhan program studi

10. Mengembangkan sistem pembelajaran melalui ICT (e-learning)

11. Mengembangan web/situs program studi

12. Membengun career development centre

Mengembangkan sistem kemitraan dalam tridharma perguruan tinggi dengan institusi akademik, industri, dan pemerintah baik dalam maupun luar negeri serta melakukan review secara berkala tentang pelaksanaan kerjasama tersebut

\section{KESIMPULAN DAN SARAN}

Lulusan program studi Manajemen harus memiliki technical competency dan behavioral competency sesuai dengan yang dibutuhkan oleh industri/dunia kerja. Informasi ini dapat diperoleh melalui tracer study. Peran tracer study semakin penting karena dapat memberikan informasi penting untuk pengembangan perguruan tinggi, berperan sebagai alat evaluasi relevansi antara pendidikan tinggi dan dunia kerja dan dapat menjadi masukan yang berguna bagi lulusan untuk meningkatkan kompetensi. Bagi stakeholders hasil tracer study dapat menjadi dasar pertimbangan dalam pemilihan perguruan tinggi yang diinginkan. Kompetensi lulusan yang harus ditingkatkan adalah bahasa Inggris, komputer, kerjasama tim, komunikasi tertulis, komunikasi lisan, pemberdayaan masyarakat, dan kepemimpinan. Peningkatan kualitas pendidikan di program studi Mnajemen dapat dilakukan melalui peningkatan kualitas pada pendidikan, penelitian, dan pengabdian kepada masyarakat, serta kerjasama dengan industri.

\section{DAFTAR PUSTAKA}

Abdullah,F., Suhaimi, R., Saban, G. \& Hamali, J. (2011). Bank Service Quality (BSQ) Index: An Indicator of Service Performance. International Journal of Quality \& Reliability Management, 28 (5). 542-555.

Hedwig, Rinda \& Polla, Geradus. (2006). Model Sistem Penjaminan Mutu dan Proses Penerapannya di Perguruan Tinggi. Graha Ilmu.

https://tucana-global.com/2017/10/27/daveulrich-the-2017-hr-competency-studywhat-it-means-for-you/

O’Neill, Peter, Sohal, Amrik, Teng, Chih Wei (2016). Quality Management Approaches and Their Impact on Firms' Financial Performance-An Australian Study. International Journal of Production Economics, 171 (3).381393.

https://doi.org/10.1016/j.ijpe.2015.07.0 $\underline{15}$

Peraturan Presiden No $8 / 2012$ tentang Kerangka Kualifikasi Nasional Indonesia (KKNI)

Publikasi Universitas Pendidikan Indonesi. (2017)

Robbins, Stephen $\mathrm{P} \&$ Judge, Timothy A. (2013). Organizational Behavior.13 $E d$. Pearson Education, Inc.Nnew Jersey.

Russel, Roberta.S \& Taylor III, Bernard W. (2013). Operations Management: Creating Value Along the Supply Chain, John Wiley \& Sons. 
Spencer \& Spencer. (2003). Competence at Work : Model for Superior Performance. John Wiley \& Sons, Inc. New York.

Supranto, J. (2006). Pengukuran Tingkat Kepuasan Pelanggan untuk Menaikkan Pangsa Pasar. Penerbit Rineka Cipta. Jakarta.

Talib, F., Rahman, Z. \& Qureshi, M. (2013). An Empirical Investigation of Relationship Between Total Quality Management Practices and Quality Performance in Indian Service Companies. International Journal of Quality \& Reliability Management, 30 (3), 280-

318. https://doi.org/10.1108/02656711 311299845

Tan, Kay C, \& Kek, Sei W. (2010). Service Quality in Higher Education Using an Enhanced SERVQUAL Approach. Journal Quality in Higher Education, 10

https://doi.org/10.1080/135383224200 0195032

The IRS Handbook on Competencies : Law and Practise (2001)

Undang Undang Nomor 44/2015 tentang Standar Nasional Perguruan Tinggi (SNPT)

Young, Jolee and Chapman, Elaine. (2010). Generic competency frameworks: A brief historical overview [online]. Education Research and Perspectives, 37 (1). Vol. 37, No. 1, 
Journal IMAGE | Volume 8, Number 1, April 2019, page 1-8 
Journal IMAGE | Volume 8, Number 1, April 2019, page 1-8 
Journal IMAGE | Volume 8, Number 1, April 2019, page 1-8 